\title{
Basal Cells with Pale Cytoplasm Present
}

National Cancer Institute

\section{Source}

National Cancer Institute. Basal Cells with Pale Cytoplasm Present. NCI Thesaurus. Code C97042.

A morphologic finding indicating the presence of basal cells in the epidermis with pale or clear-appearing cytoplasm. 